\author{
Mykhaylenko V. V., \\ Doctor of Philology, \\ Professor of the Department of Translation and Philology \\ King Danylo University
}

\title{
ON CORRELATION OF STATIC AND DYNAMIC SEMANTICS
}

Summary. This ivestigation presents a series of a comprehesive study of the word lexical meaning in-use by the author (14; 15; 16; etc). It breaks with a long semantic tradition - going back at least to Frege, and running through Montague, Davidson, Lewis and beyond - the individual sentence was in the centre of their paradigm - articulating the meaning of all linguistic expressions in terms of their contributions to the truth-conditions of the sentences in which they occur (see Hurford, Heasle, \& Smith, 2007). Accordingly, the object of ivestigation is cosidered an inherent constituent of discourse. By shifting the locus of truth-conditions in systematic theorizing to the discourse, discourse primacyshifts the centre of gravity in semantics. Therefore, that we define the meaning of a sentence in terms of its potential to contribute to the truth-conditions, or informational content, of discourses in which it can occur (Cresswell, 2002) Sadrzadeh Mehrnoosh and Reinhard Muskens (2018) underline that vector language models are based on the contextual aspects of language, the distributions of words and how they co-occur in discourse, in particular, when polysemous lexemes happen in discourse. Truth conditional models focus on the logical aspects of language, compositional properties of words and how they compose to form sentences.

We will focus on fundamental issues in static and dynamic semantics, specifically, on what is conceptually critical between the dynamic framework and the truth-conditional framework, and, consequently, the facts supporting either framework.

There are two points under discussion.

First, the article explores the consequences of cosidering the proposition as focal semantic notion characteristic of static semantic (Barbuti, Martelli, 1983) and argues that it is not limiting in accounting for discourse dynamics. In particular, the paper explores the meaning for static semantics to incorporate the notion of context change potential in a dynamic pragmatics and denies that this concept of static semantics requires that all updates to the context be eliminative and distributive.

Second, it is debative that the major difference between the two frameworks is whether semantics or pragmatics accounts for dynamics, and explores its meaning for the assumption that dynamic semantics blurs the semantics/ pragmatics distinction (Bianchi, 2004). If we refer to the category of semantics which goes back to Ludwig Wittgenstein's definition: 'the meaning of a word is its use in the language' we must admit that the word is chosen by the speaker who encodes his/her meaning with the aim for the interlocutor to decode.

Key words: static semantics, dynamic semantics, valence, context, shifting, truth-conditions, discourse.

State of the art. The concept of 'dynamic semantics' gets used in various, not always compatible ways [11, p. 231]. It applies to a range of semantic systems embracing a thesis that might be called: discourse primacy [24, p.1-2; 1, p.29], i.e. entirely discourse has truth-conditions (or more broadly, informational content). Individual sentences have truth-conditions which are decoded in discourse, or they are equal to discourse in the truth conditional approach, the denotation of a sentence determines its truth conditions, which can be taken to be a truth value, a set of possible worlds, a context change potential, or similar [20, p.320; 10, p.277].

This ivestigation breaks with a long semantic tradition - going back at least to Frege, and running through Montague, Davidson, Lewis and beyond - which revolves around the individual sentence, articulating the meaning of all linguistic expressions in terms of their contributions to the truth-conditions of the sentences in which they occur [see 3; cf. 21]. Accordingly, the object of ivestigation is cosidered as an inherent constituent of discourse. By shifting the locus of truth-conditions in systematic theorizing to the discourse, discourse primacyshifts the centre of gravity in semantics. Therefore that we define the meaning of a sentence in termsof its potential to contribute to the truth-conditions, or informational content, of discourses in which it can occur [see 8]. Sadrzadeh Mehrnoosh and Muskens Reinhard underline that vector models of language are based on the contextual aspects of language, the distributions of words and how they co-occur in discourse, in particular when polysemous lexemes are happened in discourse. Truth conditional models focus on the logical aspects of language, compositional properties of words and how they compose to form sentences [20, p.391; 13, p. 396].

We will focus on fundamental issues in dynamic and static semantics, specifically on what is conceptually at stake between the dynamic framework and the truth-conditional framework, and consequently what kinds of evidence support each framework. There are two points under discussion.

First, it explores the consequences of taking the proposition as central semantic notion characteristic of static semantics [2, p.279], and argues that this is not as limiting in accounting for discourse dynamics as one may think. Specifically, it explores what it means for a static semantics to incorporate the notion of context change potential in a dynamic pragmatics and denies that this conception of static semantics requires that all updates to the context be eliminative and distributive.

Second, it argues that the central difference between the two frameworks is whether semantics or pragmatics accounts for dynamics, and explores what this means for the frequently employed claim that dynamic semantics blurs the semantics/pragmatics distinction [see $4 ; 16]$. If we refer to the category of semantics which goes back to LudwigWittgenstein's definition: 'the meaning of a word is its use in the language'we shall add that the word is chose by the speaker who encodes his/her meaning with the aim or the interlocutor to decode.

Meaning seems at once the most obvious feature of language and the most obscure aspect to study. It is obvious because it is what we use language for - to communicate with each other, to convey 
their intentions and thoughts effectively. But the steps in understanding something said to us in a language in which we are fluent are so rapid, so transparent, that we have little conscious feel for the principles and knowledge which underlie this communicative ability [Liguistic Society of America]. The study of meaning in language is an independent level and has several subtypes, such as word grammatical, sentence and utterance meaning. There is a longstanding discussion in liguistics on static versus dynamic approaches to meaning and conversation [see $9 ; 11 ; 12 ; 18]$. A formal result due to van Benthem is often thought to be important for understanding what, conceptually speaking, is at issue in the debate [19]. One significant development in contemporary semantics, the development which has been very well debated in Linguistics and Philosophy, has met the challenge that semantics should be 'dynamic' [see 17;18]. Consequently, the meaning of a sentence should be fully considered in terms of its truth conditions, in terms of the 'potential to change truth conditions' [6, p.545]. Dynamic semantics is a perspective on natural language semantics that emphasises the growth of information in time. It is an approach to meaning representation where pieces of discourse are viewed as instructions to update an existing context with new information, with an updated context as result. The essence is that meaning is context change potential [see 12].

We would not insist that static semantics has nothing to do with "meaning" in the sense of run-time behavior, on the contrary, it is a starting point for the decoding the meaning of the word in-use: the static phase is specified by a static semantics comprising a collection of rules supporting that an expression is well-formed of a certain type. And we can uderstand the interaction between the components by "predicting" some aspects of the execution behavior of the them ensuring that they fit together properly at runtime [cf: 14, p. 101]. Then we check if our predictions are accurate; if not, the static semantics is considered to be improperly defined, and the language is deemed unsafe for execution [9, p. 95-118]. Thus, we come to the conclusion that the static semantics has been proved correct and the phrase "static semantics" tends to be a relatively uiversal term, though covering a part of the dynamic semantics [cf: 5, p. 321-345; 9, p.96].

Most scholars working on linguistic meaning or communication assume that semantics and pragmatics are distinct domains, yet there is still little consensus on how the distinction is to be drawn. We can refer to the two well-known theses: semantics is a branch of knowledge concerned with meaning (Lyons, 1977) and pragmatics is a branch of knowledge concerned with language use (Levinson, 1983) which uderlies two directios of semantic studies. We share Roby Carston's opinion that the semantics/pragmatics distinction holds between encoded linguistic meaning and speaker's meaning actualized in discourse [5, p. 321; see also 16, p. 26]. Some implications are considered for the favoured semantics/pragmatics distinction of the fact that there are linguistic elements which do not contribute to truth-conditional content but rather provide guidance to pragmatic inference [19, p. 24-48]. Further we shall focus on the relatioship of static (lexicographically registered and shared by interlocutors) and dynamic (encoded by the speaker for the hearer to decode the speaker's intention in a specific setting) features of the semantics of the lexeme minister.

Corpus analysis. I have selected the lexeme minister the lexeme seemed to be a stumble block for some interpreters (from my own interpreting experience once working at the panel discussion "The State and the Church"). Either party used to understand the word "in-use" recorded in their professional vocabulary with the context parameters. And the interpreter had to expand his/her Target language outcome adding some ethnic-cultural information instead of locating every component of the word lexical meaning in its context or situation. While analyzing the core of misunderstanding now I pinpoint the cause of the 'collision' - the interpreter should have differentiated between the static semantics registered in the dictionary and the dynamic semantics of the lexeme actualized in the speaker's discourse in the topical setting of the panel.

We shall start the analysis of the lexeme minister with its etymology which was borrowed into Middle English from Latin through Old French c. 1300 as "man consecrated to service in the Christian Church, an ecclesiastic;" in Modern English it retains the original meaning of: (1) "A man serving a church; "man consecrated to service in the Christian Church, an ecclesiastic." See Preset-Day English pastor "man caring for a church as a shepherd cares for sheep"; clergyman "belonging to a certain class"; divine is properly one learned in theology, a theologian; parson, formerly a respectful designation, is now little better than a jocular name for a clergyman; priest regards a man as appointed to offer sacrifice [Century Dictionary, 1895].

This component must be treated as a nucleus one which further on due to its use in some other settings began to actualize a covert component of a servant:

(2) The second component is that of "an agent acting for a superior, one who acts upon the authority of another," from Old French menistre "servant, valet, member of a household staff, administrator, musician, minstrel" (12c.) and directly from Latin minister (genitive ministri) "inferior, servant, priest's assistant" (in Medieval Latin, "priest"), from minus, minor "less," hence "subordinate" (from PIE root "small") + comparative suffix *-teros formed on the model of magister (see noun master ).

The given components were used in the church setting: an attendant, waiter, servant; also a priest's attendant or assistant. Then the context of service activated the component: an inferior officer, underofficial; hence, transf., an aider in a good or bad sense, a furtherer, promoter, helper, an abettor, accomplice.

(3) In 1620 s the meaning "a man in service" began to differentiate two more components: "a man heading a department" in the political setting it actualizes the component "high officer of the state, person appointed by a sovereign or chief magistrate of a country as the responsible head of a department of the government." The political sense is attested from the definition of "one who renders official service.

(4). And in the governance setting "a man not heading a department". See the component minister without portfolio (1841) "a man has cabinet status but is not in charge of a specific department" enriched word meaning in the English worldview.

(5) In the diplomatic setting the component "a diplomatic representative of a country abroad" in a French context (1709) enriched the English minister meaning.

Consequently, diachrony reveals the Latin loan word which was borrowed into English with the nucleus component "a man serving church" went on expanding its meaning due to the contextual expenditure: from religion (church) $\rightarrow$ service (administration $\rightarrow$ public service (government) $\rightarrow$ diplomacy (diplomacy). In the framework of static vs dynamic semantics correlation it can be also considered a reliable proof of an intercultural (Latin $\rightarrow$ French $\rightarrow$ English) development of the word semantic structure. 
In the following part we would like to differentiate between common and distinctive features of the word semantics employing the same lexeme functioning in British English and American English. Thus, the British lexeme minisiter includes the following components: (1) In Britain and some other countries, a minister is a person who is in charge of a particular government department (the semantic domain representing the concept 'governance' in particular executive governance); (2) minister is a person who officially represents their government in a foreign country and has a lower rank than an ambassador (the semantic domain representing the concept 'diplomacy').The Dictionary of Diplomatic Terms underlines the component common for most European countries: "The abbreviated title of the head of a legation. The full title is envoy extraordinary and minister plenipotentiary. In diplomatic ranks, that which lies below "ambassador" and above "counsellor" (or, where it is used, above "minister-counsellor", i.e. in the diplomatic ranks of some states, a position which lies beneath that of minister and above that of counsellor. (3) In the church it a member of the clergy, especially in Protestant churches the semantic domain representing the concept 'religion'(see Collins).

In the American English worldview minister is: (1) a diplomatic agent, a rank below ambassador (diplomacy); (2) in some other countries, but the USA, the name is given to high administrative offices who make up the cabinet or executive body (executive governance); (3) in Protestantism one ordained who serves (from Latin 'servant')and one not ordained (lay ministers) assists at worship services (religion, namely Protestantism) [see World Book).

In synchrony the Preset-Day English (British) worldview reflects its own shifts of components in the lexical meaning of the noun minister: The Longman dictionary gives the following order of the definition components and reveals that lexical meaning minister underwent certain shifts: (1) A politician as a governmental term referring to "a man in charge of a government department", in Britain and some other countries: minister. We would like emphathise that in the process of the politcal system development the Middle English nucleus component was shifted from the third position to the first posiition in the sematic structure of the lexeme. Black's Law Dictionary defines the term in public law referring to one of the highest functionaries in the organization of civil government, standing next to the sovereign or executive head, acting as his immediate auxiliary, and being generally charged with the administration of one of the great bureaus or departments of the executive branch of government. Otherwise it is called a "cabinet minister," "secretary of state," or "secretary of a department" in international law. It relates to an officer appointed by the government of one nation as a mediator or arbitrator between two other nations who are engaged in a controverse [see 7] (components 3-4). The religious component is "anyone authorized to carry out duties of a priest in some Christian churches pastor, vicar, Baptist minister specifies the church setting. Likewise the Middle English nucleus component (from Latin) was shifted from the first position to the third posiition [see 22, p.239]. Besides, the noun minister as a Governmental term in Britain and some other countries, referring to a politician relating to a person who is a member of the government and is either in charge, or not in in charge of a governmental department. (component 5). Minister as a diplomatic term referring to someone whose job is to represent their country in another country, a lower in rank than an ambassador: a minister witout a portfolo. The Dictioary of Diplomatic terms (online) specifies the meaning of the term in the US State diplomaic service: "a minister has traditionally been a chief of diplomatic mission who headed a legation rather than an embassy. As so few legations are left, the title is now borrowed more and more to designate the second-ranking officer of a large embassy. It has, therefore, come increasingly to refer to the senior counselor under the ambassador. To avoid confusion with the old connotation, the United States and a number of governments designate these senior deputy chiefs of mission by the hyphenated title "minister-counselor".

The comparison of dictionary entries of British English with that of American English proves 1 some 'inter-variantal' distinctive features: Merriam-Webster dictionary gives the following order of components: (1) Agent (see the angels are ministers of the divine will); (2a) one officiating or assisting the officiant in church worship; (2b) a clergyman or clergywoman especially of a Protestant communion; (3a) the superior, of one of several religious orders, see also minister-general;(3b) the assistant to the rector or the bursar of a Jesuit house; (4) a high officer of state entrusted with the management of a division of governmental activities; (5) a diplomatic representative (such as an ambassador accredited to the court or seat of government of a foreign state); (b) a diplomatic representative ranking below an ambassador.

The definitional analysis brings to light different positions of the component in the lexical meaning of the noun minister. Three components reflect Latin and French original components, however in British they are in the 3-rd and 4-th positions. The component "a high officer of state entrusted with the management of a division of governmental activities" refers to the British English and illustrated with: the British Minister of Defence. The fact is the component [in Britain and some other countries] a minister is a person who is in charge of a particular government department (the semantic domain representing the concept 'governance' in particular executive governance) corresponds to American secretary "an officer of state who superintends a government administrative department (e.g. the secretary of labor). These are two distinctive features, which verbalize two different world views. We coseder the potential of the setting of commuication (conversation) or the context of the utterace as a liguistic category to be able to activate a certain component in the lexical meaning of a word[see 23].The state or situation, or setting, or context (in our case -religio, admiistration, diplomacy) could "very well include the environment in which the receiver is embedded and thus contain an 'external' component"

Findings and perspectives. In closing, we want to reiterate the close relationship of sematics and pragmatics as branches of linguistics. However, as different disciplines, they are only similar in that both deal with meaning.

This ivestigation breaks with a long semantic tradition - going back at least to Frege (see also the works by Montague, Davidson, Lewis ad others) when the individual sentence used to be the centre of the liguistic paradigm [see 3 ; cf. 21]. Accordingly, the object of ivestigation is considered as an inherent constituent of discourse. By shifting the locus of truth-conditions in systematic theorizing to the discourse, discourse primacyshifts the centre of gravity in semantics. Therefore, we define the meaning of a sentence in termsof its potential to contribute to the truth-conditions, or informational contentof discourse in which it can occur.

Dynamic semantics is a perspective on natural language semantics that emphasises the growth of information in time. It is an approach to meaning representation where chunks of text or 
discourse are viewed as instructions to update an existing context with new information, with an updated context as result. We have focused on fundamental issues in dynamic and static semantics, specifically on what is conceptually critical between the dynamic framework and the truth-conditional framework, and, consequently, what kinds of evidence support each framework. There are two points under discussion (see Barbuti R., Martelli, 1983).

First, it explores the consequences of taking the proposition as a focal semantic notion characteristic of static semantics and argues that this is not limiting in accounting for discourse dynamics.

Second, it argues that the major difference between the two frameworks is whether semantics or pragmatics accounts for dynamics, and explores what the meaning of this assumption for the frequently employed assertion that dynamic semantics blurs the semantics/pragmatics distinction (Cruse, 2013). If we refer to the category of semantics which goes back to LudwigWittgenstein's definition: 'the meaning of a word is its use in the language "we shall add that the word is chose by the speaker who encodes his/her meaning with the aim or the interlocutor to decode.

Finally, it has often been noted the importance of observing that using dynamic semantics one can define other meaning relations that resemble consequence relation.

\section{References:}

1. Aloni Maria,Van Rooy R..The dynamics of questions and focus. Proceedings of SALT. 2012. Vol. 12. P. 20-39.

2. Barbuti R., Martelli A. A structured approach to static semantics correctness. Science of Computer Programming. 1983. Vol. 3. P. 279-311.

3. Beaver David I. Presupposition and assertion in dynamic semantics. PhD. Thesis, CCS. Edinburgh: University of Edinburgh, 1995. 289 p.

4. Bianchi Claudia. The semantics / pragmatics distinction. Stanord: CSLI Publications, 2004. 204p.

5. Carston Robyn Anne. Linguistic communication and the semantics/ pragmatics distinction. Synthese. 2008. Vol. 165 (3). P. 321-345.

6. Cresswell M. J.Static semantics for dynamic discourse. Linguistics and Philosophy. 2002. Vol. 25. P. 545-571.

7. Garner Bryan A. Black's Law Dictionary. New York: Thomson West, 2014. $2052 \mathrm{p}$.

8. Heim Irene. On the projection problem for presuppositions. / Ed. I.P. Portner, B.H. Partee. Formal semantics. The Essential readings. London: Blackwell, 1983. P. 2.

9. Jones Neil D. Static semantics, types, and binding time analysis. Theoretical Computer Science. 1991. Vol. 90. P. 95-118.

10. Kamp Hans. A Theory of truth and semantic representation / Ed. J. Groenendijk, TH. Janssen and M. Stokhof. Formal Methods in the Study of Language. Part I. Amsterdam: Mathematisch Centrum, 1981. P. 277-322.

11. Lewis Karen S. Do we need dynamic semantics? / Ed. Alexis Burgess,Brett Sherman. Metasemantics: New essays on the foundations of meaning. Oxford: Oxford University Press, 2014. P. 231-258.

12. Lewis Karen S. Dynamic semantics. Oxford Handbooks Online. 2017.

13. Muyskens Reinhard, van Benthem Johan, and Visser Albert. Dynamics./ Ed. Johan van Benthem and Alice ter Meulen. Handbook of Logic and Language. Amsterdam: Elsevier, 1997. P. 587-648.

14. 14 Mykhaylenko V.V. Functional semantics of apposition in the author's discourse: Contrastive aspect. Наукові записки ціонального університету «Острозька академія». Серія: Філологічна. Вип. 61. 2016. P. 5-8.

15. Mykhaylenko V.V. Functional semantics of the adjective "clever" in discourse. / Ed. C.М. Єнікєєва. Нова філологія : збірник наукових праць. Запоріжжя: ЗНУ, 2017. № 72. С. 101-107.
16. Mykhaylenko V.V. Graduality in lexical semantics of L1 and L2: A Case for "layman" in English and Russian. Вісник Харківського наиіонального університету імені В.Н. Каразіна. Серія «Іноземна філологія. Методика викладання іноземних мов». 2016. Вип. 84. C. 26-32.

17. Napoletano Toby. Semantics, meaning, truth and content: Disentangling linguistic and philosophical approaches to the study of meaning. Doctoral dissertations. Storrs: University of Connecticut, 2017. 251 p.

18. Nouwen Rick, Adrian Brasoveanu Adrian, Eijck Jan van, Visser Albert. Dynamic semantics. Stanford Encyclopedia of Philosophy online. 2016.

19. Rothschild Daniel, Yalcin Seth. On the dynamics of conversation. Noûs. 2017. Vol. 51 (2). P. 24-48.

20. Sadrzadeh Mehrnoosh,Muskens Reinhard. Static and dynamic semantics. Vector for lambda calculus models of natural language. Journal of Language Modelling. 2018. Vol. 6 (2). P. 319-351.

21. van Benthem J. Exploring logical dynamics. Stanford: CSLI Publications, 1996.

22. van Eijck Jan. The dynamics of descriptions. Journal of Semantics. 1993. Vol. 10. P. 239-267.

23. van Eijck J., Visser A. Dynamic semantics. / Ed. E.N. Zalta. The Stanford Encyclopedia of Philosophy online. 2010.

24. Yalcin Seth. Introductory notes on dynamic semantics / Ed. D. Fara, G. Russell. Routledge Companion to the Philosophy of Language. London, New York: Routledge, 2012. P. 253-279.

\section{Sources of illustrative material:}

1. Barbuti R., Martelli A.A Structured Approach To Static Semantics Correctness. Science of Computer Programming. Science of Computer Programming. 1983. Vol. 3. P. 279-311.

2. Cruse Alan. Meaning in Language: An Introduction to Semantics and Pragmatics. Oxford: Oxford University Press. 2011. 497 p.

3. Hurford J., Heasly, B., Smith M. Semantics. Cambridge: Cambridge University Press, 2007.

4. Levinson C.S. Pragmatics. Cambridge: Cambridge University Press.1983. $420 \mathrm{p}$.

5. Lyons, J. Semantics. Cambridge: Cambridge University Press, 1977. $897 \mathrm{p}$.

6. Mykhaylenko V.V. A Glossary of Linguistics and Translation Studies: English-Ukrainian. Ivano-Frankivsk: King Danylo Galitskiy University of Law, 2015. 528 .p

7. Mykhaylenko V.V. Conceptual analysis: componential analysis. Hayковий вісник Чернівещького нащіонального університету імені Юрія Федьковича. Германська філологія. 2014. № 720. Р. 77-86.

8. Williams M.H. Methods for specifying static semantics. Computer Languages. 1981. Vol. 6 (1). P. 1-17.

Михайленко В. В. Про співвідношення статичної та динамічної семантики

Анотація. Стаття продовжує серію робіт автора, присвячених вивченню лексичного значення слова в узусі [13; 14; 15 і т. д.]. Вона свідчить про відхід від багаторічної семаничної традиції, яка сягає теорії Фреге і розвинута у роботах Монтегю, Девідсона, Льюїса та інших авторів. Зазвичай у межах зазначеної теорії знаходиться автономне речення, що представляє всі типи значення з позиції їх ролі У вираженні умови коректності речення (див. Хьорфорд, Хіслі, Сміт, 2007).

Відповідно об'єкт дослідження вважається невід'ємною складовою частиною дискурсу. Пересув локусу 3 речення на дискурс $є$ передумовою коректності системного теоретичного дослідження дискурсу, дискурс стає семаничним центром дослідження. Отже, ми визначаємо значення речення в термінах його потенціалу формування змісту дикурсу, де воно може прявити свою коректність 
(Крессвел, 2002). Мернуш і Мускенс (2018) підкреслюють, що векторні моделі мови грунтуються на контекстних характеристиках мови, дистрибуції слів і тому, як вони реалізуються в дискурсі, зокрема коли в дискурсі функціонує багатозначна лексика. Моделі з істиною коректністю базуються на логічних аспектах мови, композиційних властивостях слів і тому, як вони формують речення.

Ми зосередимося на фундаментальних питаннях статичної та динамічної семантиці, на концепуальній різниці між динімічною рамкою та рамкою коррекності, фактами, які підтримують ту чи іншу тезу.

По-перше, у статті досліджуються наслідки прийняття пропозиції як головного семаничного поняття, характерного для статичної семантики (Барбуті, Мартелі, 1983) і дискутується, що такий підхід не означає обмеження для дискурсивної диниміки. Зокрема, розглядається факт включення поняття змінного контексту до динамічної прагматики та заперечується, що концепція статичної семантики вимагає, щоб усі зміни контексту були елімінативного та дистрибутивного харакеру.

По-друге, заперечується, що основною відмінністю між цими двома конструкторами $є$ фактор динаміки. Також приділено увагу твердженню, згідно з яким динамічна семантика розмиває межі семантики / прагматики (Біанчі, 2004).

Якщо ми посилаємося на категорію семантики, визначену Людвігом Вітгенштейном як «значення слова - в його функціонуванні в мові», ми маємо додати, що це слово дібрано мовцем для передачі інтенціонального значення.

Ключові слова: статична семантика, динамічна семантика, валентність, контекст, пересув, умови істинності, дискурс. 